Vitalii V. Khomicky, PhD, Associate professor of the Department of Applied Hydrodynamics of Institute of Hydromechanics of the NAS Ukraine ORCID ID: 0000-0003-0910-2233e-mail: homicky@ukr.net

Volodymyr A. Voskoboinick, DSci, Associate professor of the Department of Hydrobionics and Boundary Layer Control of Institute of Hydromechanics of the NAS Ukraine ORCID ID: 0000-0003-2161-6923e-mail:vlad.vsk@gmail.com

Anatolii G. Kharchenko, Senior engineer electrician of the Department of Applied Hydrodynamics of Institute of Hydromechanics of the NAS Ukraine ORCID ID: 0000-0002-5832-7714 e-mail: kharchenko62@gmail.com

Oleksandr A. Voskoboinyk, $\mathrm{PhD}$, Associate professor of the Department of Technical Hydromechanics of Institute of Hydromechanics of the NAS Ukraine

ORCID ID: 0000-0001-8114-4433e-mail: alexandr.vsk@gmail.com

Lidiia M. Tereshchenko, $\mathrm{PhD}$, Associate professor of the Department of Applied Hydrodynamics of Institute of Hydromechanics of the NAS Ukraine ORCID ID: 0000-0001-6068-7092 e-mail: litere70@ gmail.com

Andrey V. Voskoboinick, PhD, Associate professor of the Department of Hydrobionics and Boundary Layer Control of Institute of Hydromechanics of the NAS Ukraine ORCID ID: 0000-0001-8045-8625 e-mail: andrew.vsk@gmail.com

Ivan A. Nikitin, Senior engineer of the Department of Applied Hydrodynamics of Institute of Hydromechanics of the NAS Ukraine ORCID ID: 0000-0001-5906-2538 e-mail: nia37@ukr.net

Institute of Hydromechanics of the NASU, Kyiv, Ukraine

\title{
DEFENSE OF BEACH BY ACTIVE COAST-PROTECTING STRUCTURES
}

\begin{abstract}
The results of physical modeling of recreational beach protection by active protection methods are presented. The experiments were carried out in the wave pool on models of intermittent breakwaters with $T$-shaped and $V$-shaped traverses and dike dam systems. The use of active shore protection methods makes it possible to preserve natural and artificial beaches with the formation of a stable coastline. The geometrical parameters and hydrodynamic characteristics of the shore protection structures are established and recommendations for their operation are developed. Based on the research results, the dike dam system has been put into practice to protect the coastal strip of the "Urzuf" recreation complex on the shore of the Sea of Azov.
\end{abstract}

Key words: recreation beach; coast-protecting structure; wave motion; dike dam; breakwater; wave pressure

(C) V.V. Khomicky, V.A. Voskoboinick, A.G. Kharchenko, O.A. Voskoboinyk, L.M. Tereshchenko,

A.V. Voskoboinick, I.A. Nikitin, 2019 
В.В. Хомицький, В.А. Воскобійник, А.Г. Харченко, О.А. Воскобойник, Л.М. Терещенко, А.В. Воскобійник, І.А. Нікітін

Інститут гідромеханіки НАН України, м. Київ, Україна

\title{
ЗАХИСТ ПЛЯЖУ АКТИВНИМИ БЕРЕГОЗАХИСНИМИ СПОРУДАМИ
}

\begin{abstract}
Анотація. Наведено результати фізичного моделювання захисту рекреаційного пляжу активними методами захисту. Експерименти проведено в хвильовому басейні на моделях переривчастих хвилеломів 3 T-подібними та V-подібними траверсами і системами бун. Використання активних методів берегозахисту дає можливість зберегти природні і штучні пляжі з утворенням стійкої берегової лінії. Встановлено геометричні параметри $і$ гідродинамічні характеристики берегозахисних споруд та розроблено рекомендації їх експлуатаиії. На підставі отриманих результатів досліджень впроваджена на практииі система бун для захисту прибережної смуги оздоровчого комплексу "Урзуф" на березі Азовського моря.
\end{abstract}

Ключові слова: рекреачійний пляж; берегозахисна споруда; хвильовий рух; буна; хвилелом; хвильовий тиск

\section{Вступ}

Проблема захисту берегової лінії та зокрема пляжної полоси санаторнокурортної зони оздоровчого комплексу “Урзуф”, який розташовано поблизу Білосарайської та Бердянської ділянок Північно-Азовського району Північної берегової області Азовського моря, виникла через дію хвильового навантаження на берег та вздовжберегових течій. До Білосарайської ділянки примикає акумулятивна форма коси Білосарайська та на східному фланзі кореневий берег абразійно-обвального та абразивно-зсувного типів. В геологічній будові берегів беруть участь лисовидні суглинки, пісок та глина. Тип розчленування берегів абразійно-бухтовий. Характерним $є$ порівняльно велика кількість (від 2 до 33\%) пляжебудуючого матеріалу (діаметр більше або близько 0,1 мм). Пляж та підводний береговий схил викладені добре сортованим середньозернистим піском. На урізі води матеріал укрупнюється в результаті накопичення вапняних кульок гравія та ракуші. Ухил дна до ізобати 2 м складає 0,017-0,029 [1].

Відомо [1-3], що головним чинником руйнування берегової зони є хвилева абразія, активація якої спричинена підвищенням рівня моря, збільшенням повторюваності та інтенсивності штормів, безсистемним і необгрунтованим будівництвом берегозахисних і берегоукріплювальних споруд та іншими чинниками. Заходи з будівництва берегозахисних споруд належать до природоохоронних і направлені на відвернення (призупинення) небезпечних геологічних процесів, з метою запобігання руйнуванню берега, втраті цінних лікувальних та земельних ресурсів рекреаційної зони. Під час проектування та будівництва берегозахисних споруд треба дотримуватися норм і вимог щодо водоохоронних зон, а також охорони природних комплексів та об'єктів національних природних парків, щодо охорони морського середовища та прибережної захисної смуги [3, 4].

Берегозахисні споруди повинні зменшувати дію хвиль на береговий схил та пляжну полосу, а також регулювати переміщення наносів у прибережній зоні 
моря 3 метою збереження та відновлення пляжу, як основного елемента захисту берегів. Берегозахисні заходи повинні зберігати та покращувати екологічну обстановку у прибережній зоні моря та на прилеглій частині суші. Берегозахисне будівництво в умовах існування вздовжберегового переносу наносів повинно проводитися назустріч їх потоку з обов'язковим захистом від розмиву низових ділянок берега [2-4].

За способами захисту берегів споруди діляться на дві групи: пасивні або активні берегозахисні споруди [5, 6]. Пасивні берегозахисні споруди сприймають на себе дію хвиль та зменшують їх енергію завдяки своїй конструкції. Споруди пасивного способу дії безпосередньо захищають береговий укіс від впливу хвилювання та течії. Вони здійснюють таким чином тільки завдання збереження ділянки берега, який існував до їх зведення. Сюди відносяться поздовжні берегоукріплювальні стінки і споруди укісного, напівукісного і ступеневого типів, штучні пляжі, хвилегасячі берми, а також берегові дамби.

Активні берегозахисні споруди зберігають пляжі або створюють умови для формування пляжів, зменшуючи енергію, висоту та період штормових хвиль. В значній мірі енергія хвиль гаситься на підході до берега. Берег зміцнюється спорудами, що затримують наноси, в результаті чого перед цією ділянкою берега утворюється захисна смуга пляжу $[7,8]$. До числа активних способів захисту відносять поперечні буни, надводні і підводні хвилеломи, банкети, підводні рівчаки, штучні миси, поздовжні берегоукріплювальні хвилерізи та інше.

Для захисту берегової лінії в акваторіях портів застосовують споруди пасивного методу захисту. На відкритому морському узбережжі найчастіше застосовується активний метод захисту або споруди комбінованого типу. В останні десятиліття все більше поширення в практиці штучного пляжеутворення знаходять пляжі бухтового контуру берега із штучними мисами під захистом бунних конструкцій. Світовий досвід показує $[3,7,8]$, що найбільш ефективним способом берегозахисту є утворення штучних пляжів. Такі пляжі можуть застосовуватися як на природному березі, так і в штучних бухтових берегових формах, де утворюється оборотна циркуляція наносів 3 використанням вздовжберегового і глибинного байпасінгу. Штучні бухти 3 мисами можуть бути різної конфігурації.

Буни представляють собою штучні споруди, розташовані перпендикулярно або під кутом до берега і підносяться над поверхнею води, або занурюються під воду. Призначення бун - перепинити шлях руху вздовж берегових наносів і сприяти таким чином розширенню пляжу [9, 10]. Крім того, при наявності вздовжберегових течій, що підмивають береги, буни відхиляють їх. На затінених від хвилювання ділянках міжбунних проміжків ширина пляжу мінімальна. За наявності вздовжберегового потоку наносів, наноси заповнюватимуть кут, обернутий назустріч течії [11].

За конструкцією хвилеломи [12] мало відрізняються від кореневих ділянок захисних споруд. Гребінь незатопленого берегозахисного хвилелому може значно підніматися над рівнем моря. Для зменшення хвильової дії на споруду, виключення утворення відбитих хвиль 3 їх небезпечною дією з розмивання грунту, накопичення наносів в захвильовому просторі і скорочення вартості споруди подібні конструкції будують із затопленим гребнем і звичайно називають підводними хвилеломами $[13,14]$. На них відбувається гасіння 
хвиль на 50\%, решта хвильової енергії гаситься природним або штучним відсипаним пляжем. Для запобігання утворенню між хвилеломом і берегом вздовжберегових течій, що спричиняють переміщення наносів, підводний хвилелом сполучають з берегом траверсами $[13,15]$.

Мета роботи - визначення за допомогою фізичного моделювання найбільш ефективних берегозахисних споруд активного способу захисту, які використовуються в умовах дефіциту наносів хвильового поля, характерних для Білосарайської та Бердянської ділянок Північно-Азовського району Північної берегової області Азовського моря.

\section{Експериментальний стенд, програма та методика досліджень}

У хвильовому басейні на полігоні Інституту гідромеханіки НАНУ були проведені експериментальні дослідження різної компоновки берегоукріплювальних споруд для вибору оптимального варіанту захисту берегової полоси для попередження розмиву рекреаційного пляжу. Полігон знаходиться на березі Дніпра у Київській області [14]. На полігоні хвильові

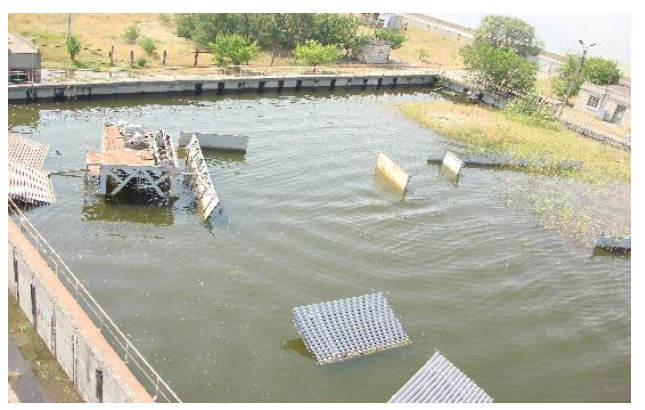

a)

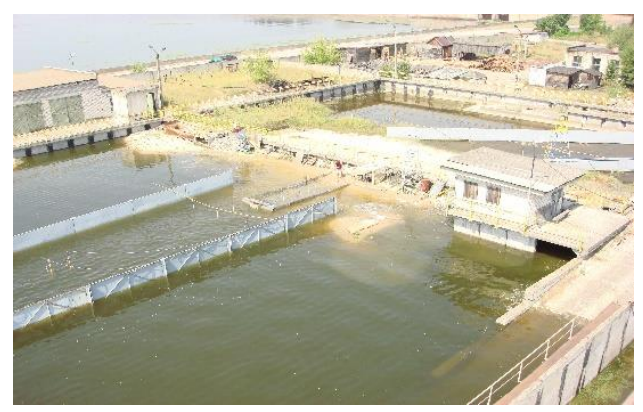

б)

Рис. 1 - Великий (а) та малий (б) хвильові басейни на полігоні Інституту гідромеханіки НАН України

басейни в плані представляють собою прямокутники зі сторонами $67 \times 43$ м та $43 \times 27$ м і висотою огороджувальних стінок 2 м; глибина наповнення басейну водою складає 0,9 м. Фотографія хвильових басейнів наведена на рис. 1 . Басейни обладнані щитовими хвилеутворювачами, які породжували хвилі регульованої та контрольованої висоти від 0,02 м до 0,4 м та періоду від 0,5 с до 2 с. Крім того, в басейнах знаходяться відповідні засоби реєстрації та контролю параметрів хвиль, швидкостей течії, хвильових тисків та навантажень, системи візуалізації дослідів. Вони обладнані приладами обробки та аналізу експериментальних результатів, відео- і фотоапаратурою та допоміжними засобами.

Прийнята для фізичного моделювання довжина берега в натурі поблизу оздоровчого комплексу "Урзуф" склала 1,8 км. Оскільки це дуже велика довжина, то навіть в масштабі для фізичного моделювання брались окремі фрагменти систем бун з відповідною підготовкою природного рельєфу. В усіх дослідах вертикальний та горизонтальний масштаби моделі складали відповідно 1:20 та 1:90. 
Під час моделювання задачі хвильового руху рідини дотримувались умови автомодельності за числом Рейнольдса [16], яке розраховувалося за залежністю

$$
R e=\frac{V_{x} H}{v}
$$

де $V_{x}$ - усереднене значення горизонтальної складової орбітальної швидкості по глибині потоку $H$ та за період хвилі,

$$
V_{x}=\frac{h \lambda}{\pi \tau H}+\frac{\operatorname{sh}^{2} \operatorname{ch} \frac{2 \pi H}{\lambda}}{A \tau H \operatorname{sh}^{3} \frac{2 \pi H}{\lambda}} .
$$

Проведені розрахунки за залежностями (1) та (2) показують, що в наших експериментах значення числа Рейнольдса складає $\operatorname{Re}=(1 \ldots 10) \cdot 10^{6}$, що більше критичного значення у відповідності до рекомендацій $[14,16]$. Таким чином, розрахункові залежності, отримані за дослідними даними, можуть бути використані для натурних умов.

Для даних дослідів брались: розрахункові параметри хвиль формуються 3 крутизною, що характерна для фази розвитку шторму $\left(\lambda_{0} \approx 12\right)$.

Приймаючи до уваги клас захисних споруд, забезпеченість розрахункового шторму прийнята $\mathrm{p}=4 \%$; забезпеченість висот хвиль в системі відповідно $\mathrm{p}=1 \%$ та $\mathrm{p}=5 \%$ при дослідженні розмиву підводного берегового схилу. В дослідах на фізичній моделі розглядалась дія штормового хвилювання від Пд3 ( $\left.\theta=42^{\circ}\right)$.

Осереднені значення параметрів хвиль $(\mathrm{p}=1 \%)$ при косому (Пд3) підході хвиль рівні: $\mathrm{h}_{1 \%}=2,0 \mathrm{~m} ; \bar{\lambda}=21 \mathrm{~m} ; \bar{\tau}=3,67$ с. 3 урахуванням масштабу моделювання на моделі параметри хвиль були наступними: $\mathrm{h}_{\mathrm{m}}=0,10 \mathrm{M}$; $\bar{\lambda}_{\mathrm{M}}=1,05 \mathrm{M} ; \bar{\tau}_{\mathrm{M}}=0,82 \mathrm{c}$.

Вимірювання параметрів хвиль і їх контроль здійснювалися за допомогою датчиків статичного і динамічного тиску та пульсацій тиску. Датчики були виготовлені на базі п'єзорезистивних і п'єзокерамічних чутливих елементів $[17,18]$. Датчики було установлено в кореляційні блоки по декілька датчиків у кожному та змонтовано урівень 3 обтічною поверхнею досліджуваних об’єктів. На рис. 2 наведені фотографії датчиків та їх розташування

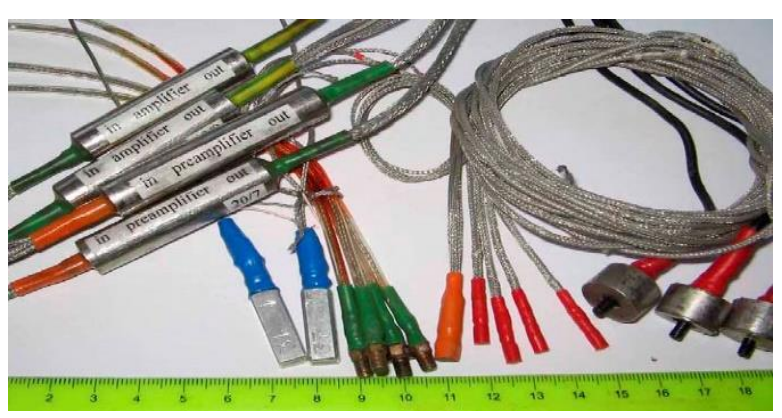

a)

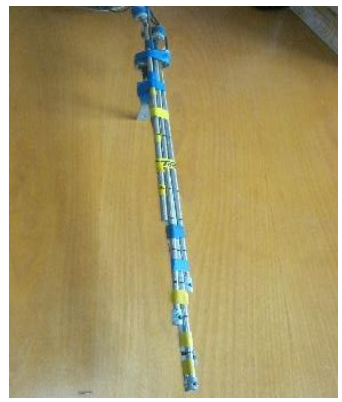

б)

Рис. 2 - П'єзорезистивні та п’єзокерамічні датчики тиску (а) і кореляційний блок датчиків повного тиску (б) 
у кореляційних блоках. Висота хвиль та хвильовий тиск по глибині хвильового потоку реєструвалися кореляційним блоком у вигляді переносної вертикалі датчиків. Так, на рис. 26 представлено кореляційний блок 3 чотирма п'єзорезистивними датчиками повного тиску. Довжина хвиль вимірювалася двома кореляційними блоками, які розташовувалися на заданій відстані у напрямку руху хвилі. Висота і період хвиль визначалися з осцилограм тиску хвильового руху, а також із спектральних густин потужності пульсацій хвильового тиску.

Електричні сигнали датчиків після відповідного підсилення та фільтрування потрапляли на 8-канальні або 16-канальні аналогово-цифрові перетворювачі (АЦП), які було установлено у персональні комп'ютери. У дослідах використовувалися перетворювачі фірми "National Instruments" (16-бітовий АЦП PCI-6031E) і фірми "L-Card" (12-бітовий АЦП L-154 та 14-бітовий АЦП Е-14-440). Цифрові сигнали оброблялися і аналізувалися на комп'ютерах за відповідними програмами та алгоритмами з використанням апарату теорії ймовірності та математичної статистики.

Для дослідження хвильового руху та його дії на моделі берегозахисних споруд i пляжні зони використовувалися статистичні методи аналізу експериментальних даних $[19,20]$. Так, статистичний опис характеризує розподіл вірогідності параметрів хвиль, хвильових навантажень і реакцій споруди на дію хвиль. Він базується на застосуванні методів математичної статистики і теорії ймовірності до обробки та аналізу даних, одержаних під час спостережень за хвилюванням в лабораторних умовах [19]. На основі статистичного аналізу можна передбачити характеристики хвиль, які можуть з'явитися із заданою вірогідністю, або вірогідність перевищення реакцій споруд заданого рівня.

Суть статистичного аналізу, який є найсучаснішим методом математичної фізики та прикладної математики, полягає в представленні реального тривимірного хвилювання у вигляді набору гармонійних хвиль, різних за амплітудою, по-різному зсунутих за фазою і які розповсюджуються у різних напрямах. Для кожної складової приймаються справедливими закономірності, встановлені в гідродинамічній теорії, а розподіл енергії між окремими частотами i напрямами визначається енергетичним спектром найважливішою характеристикою хвиль в спектральному описі. Під час знаходження енергетичного спектру використовують результати статистичної обробки даних лабораторних або натурних спостережень.

Основною характеристикою в спектральному описі хвилювання $\epsilon$ енергетичний спектр, або функція спектральної густини потужності хвильового тиску, $P(\omega)$, яка встановлює розподіл енергії хвильового тиску по частотах хвиль $[19,21]$. Спектральна густина потужності пульсацій хвильового тиску розраховувалася за залежністю:

$$
P(\omega)=\frac{1}{2 \pi} \int_{-\infty}^{\infty} R_{p_{1} p_{2}}(\tau) \exp (-i \omega \tau) d \tau
$$

де $R_{p_{1} p_{2}}(\tau)$ - автокореляційна функція пульсацій хвильового тиску, які виміряно 3 затримкою у часі $\left(\tau=\mathrm{t}_{2}-\mathrm{t}_{1}\right)$. Автокореляційну функцію розраховували за залежністю: 


$$
\begin{gathered}
\sim 66 \sim \\
R_{p_{1} p_{2}}=\left\langle p_{1}(\vec{x}, t) p_{2}(\vec{x}, t+\tau)\right\rangle
\end{gathered}
$$

де дужки 〈 > вказують на усереднення пульсацій хвильового тиску за ансамблем.

Якщо ж енергетичний спектр відомий, то, навпаки, по ньому можуть бути одержані статистичні характеристики, зокрема середньоквадратичні значення висоти та періоду хвиль, які вираховуються за наступними залежностями:

$$
\begin{gathered}
\bar{h}=\left[2 \pi \int_{0}^{\infty} P(\omega) d \omega\right]^{1 / 2} \\
\bar{\tau}=2 \pi\left[\frac{\int_{0}^{\infty} P(\omega) d \omega}{\int_{0}^{\infty} P(\omega) \omega^{2} d \omega}\right]^{1 / 2}
\end{gathered}
$$

Згідно із залежностями (5) і (6) були отримані інтегральні характеристики вихрового руху у вигляді середньоквадратичних значень висот хвиль та їх періоду, а також спектральні густини потужності пульсацій хвильового тиску, які розраховувалися за залежністю (3) з урахуванням залежності (4).

Похибка вимірювань усереднених та інтегральних величин висот хвиль і тисків не перевищувала 5\% (надійність 95\%). Похибка вимірювань спектральних характеристик поля пульсацій хвильового тиску не більше 2 дБ для спектральних густин потужності пульсацій тиску в діапазоні частот від 0 Гц до 1,25 кГц. Вимірювання кореляційних характеристик полів тиску та параметрів хвиль мали похибку не більше $8 \% 3$ довірчою ймовірністю 0.95 або $2 \sigma$.

\section{Результати досліджень}

Згідно з розробленою програмою та методикою досліджень було розроблено і створено декілька варіантів моделей фрагментів берегозахисних споруд i проведено ряд дослідів, серед яких можна виокремити наступні, які $\epsilon$ характерними для досліджуваних конструкцій. Однією 3 конструкцій берегозахисних споруд, які захищали моделі пляжів, були буни, установлені перпендикулярно до берегової лінії. В лабораторних умовах модель пляжу було зроблено 3 піщаних наносів, де ефективний діаметр піщинок складав $\bar{d}=0,35$ мм. 3 метою вироблення і закріплення рельєфу природного прототипу ділянки захисту дослід проводився на позначці середньобагаторічного рівня води при тривалості дії хвиль 25 тис., після чого модель досягала стану динамічної рівноваги. Надалі на модель продукувався попуск в 3,5 тис. хвиль на нагінному $(+0,035$ м чи $+0,7$ м в натурі) рівні. Загальна довжина ділянки на моделі 16 м (1,45 км в натурі). Розміри та відмітки моделі бун складали $(0,56-0,87)$ м; міжбунні відстані - $(1,15 \ldots 1,78)$ м, що відповідало натурним розмірам: (50-80) м та (100-160) м, відповідно. Хвильовий режим на глибокій воді $(h=0,096 \mathrm{~m} ; \bar{\tau}=0,82 \mathrm{c})$ відповідав в натурі $(h=2,0 \mathrm{м} ; \bar{\tau}=3,67 \mathrm{c})$.

Вихідні висоти хвиль до руйнування на критичних глибинах змінювались по фронту моделі від 0,08...0,09 м (1,6..1,8 м в натурі); в районі підводного валу висоти зруйнованих хвиль змінювались від 0,06..0,065 м $(1,2 \ldots 1,3$ м в натурі); на лінії голів бун перед набіганням на відкіс висоти хвиль складали 
0,045 ...0,055 м $(0,9 \ldots 1,1$ м в натурі). Відмілість берега визначала виражену рефракцію хвиль, в результаті чого до урізу води хвилі накочувалися під кутом $10 \ldots 15^{\circ}$, що є близьким до фронтального підходу хвиль.

Загальний вигляд моделі до, під час та після досліду показано на рис. 3. Установлено, що під дією хвильового руху, який було спрямовано під кутом 42 градуси до моделі берегозахисної споруди, відбувається розмив пляжу біля навітряних сторін бун і намив грунту біля підвітряних сторін бун. Поблизу голів бун зареєстровано значний розмив грунту. В ході експерименту поверхня берегового схилу піддавалася деформації. Спочатку вирівняна поверхня моделі пляжу до кінця досліду набула криволінійних обрисів, ускладнених наявністю улоговини та валу (див., рис. 3в).

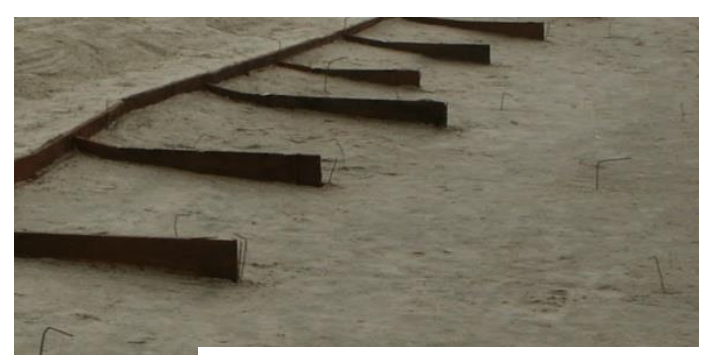

a)

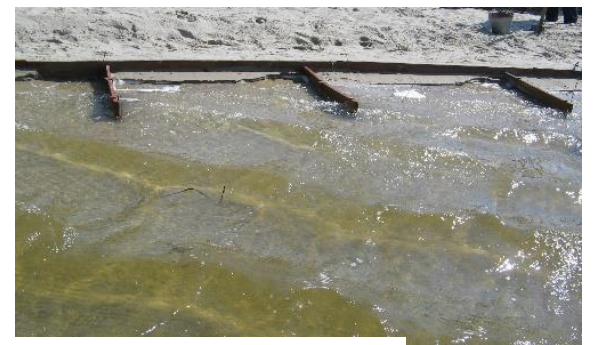

б)

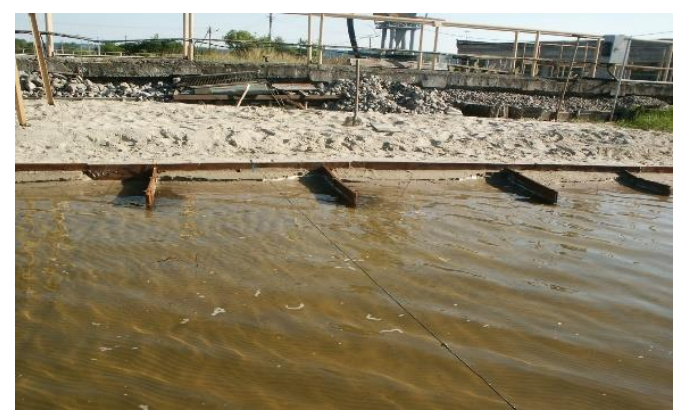

B)

Рис. 3 - Загальний вигляд моделі берега з бунами до (a), під час (б) та після (в) проведення досліджень

На рис. 4 наведено результати вимірювань висоти та періоду хвиль у вигляді осцилограми хвильового тиску та спектральної густини потужності пульсацій хвильового тиску, які виміряні в умовах глибокої води перед моделлю берегозахисної споруди. Результати досліджень показують, що хвильовий режим руху рідини, який генерує щитовий хвилеутворювач, має достатньо однорідний коливальний характер. Амплітуда хвильового тиску змінюється близько 1 кПа, що відповідає висоті хвилі 0,097 м (або близько 2 м у натурі), як показано на рис. 4а. Період модельної хвилі складає 0,82 с, що узгоджується 3 періодом натурної хвилі $\bar{\tau}=3,67$ с. У спектрі пульсацій хвильового тиску спостерігаються три тональні гармоніки, які відповідають частотам 1,22 Гц, 2,44 Гц та 3,66 Гц. Перша частота - це основна частота хвильового руху періодом $0,82 \mathrm{c}$, а інші - це друга та третя гармоніки основної частоти. Спектральні рівні пульсацій хвильового тиску зі збільшенням частоти поступово зменшуються (див. рис. 4б). 
Осцилограми хвильового руху та спектри пульсацій хвильового тиску поблизу моделі берегозахисної споруди показані на рис. 5. Так, на рис. 5а наведені результати досліджень хвиль до їх руйнування на критичних глибинах, на рис. 5б наведені результати досліджень поблизу області обвалення хвиль, а на рис. 5в - на лінії голів бун перед набіганням хвиль на відкіс модельного пляжу. Згідно з наведеними результатами досліджень 3 наближенням хвильового руху до моделей берегозахисних споруд та відкосів пляжів спостерігається зменшення висоти хвиль, а їх період залишається незмінним. Поблизу критичних глибин виявлено руйнування верхньої частини хвиль, яке збільшується з наближенням до берега. В області обвалення хвиль та на рівні голів бун поблизу відкосу модельного пляжу виявлено руйнування підошви хвиль, що більш наглядно спостерігається на рис. 5в.

У спектрах пульсацій хвильового тиску з наближенням до берегової лінії має місце зменшення спектральних рівнів пульсацій хвильового тиску в області низьких частот, а особливо на тональних складових коливального процесу. Разом з цим спостерігається підвищення спектральних складових пульсацій хвильового тиску в області високих частот, що обумовлено генерацією дрібномасштабних вихрових структур і струменевих течій через руйнування хвиль у прибережній зоні.

Таким чином, результати досліджень параметрів хвильового процесу та дії хвиль на модель фрагменту ділянки бунного захисту піщаного пляжу показали, що з наближенням до берегової лінії спостерігається трансформація хвильового руху. В першу чергу зменшуються висоти хвиль з незмінним їх періодом, відбувається руйнування хвиль і генерація дрібномасштабних структур, що викликає зменшення низькочастотних складових спектру пульсацій хвильового тиску та збільшення високочастотних складових спектру.

На основі результатів досліджень моделі ділянки берегозахисної споруди у вигляді системи бун установлено, що в міжбунному просторі існуючі висотні відмітки та ширина природного пляжу не достатні для збереження рекреаційної поверхні пляжу під час дії хвиль на нагонному рівні.

Наступною моделлю берегозахисних споруд досліджувалися Т-подібні хвилеломи 3 бунами у вигляді траверс. В цьому випадку до бун, результатидосліджень 3 якими було наведено раніше, додавалися перпендикулярно розташовані хвилеломи довжиною 0,5 м (45 м у натурі). Довжини бун та міжбунних проміжків залишилися незмінними. У міжбунних областях піщану берму було зроблено аналогічно попередньому досліду. Загальний вигляд моделі берегозахисної споруди до, під час та після досліду показано на рис. 6. Дослідження показали, що створення бухт дозволило зберегти площу рекреаційного пляжу, в тому числі і під дією хвиль на нагонному рівні. Практично близько 80\% початкового об'єму берми не перероблялося хвилями. Обсяг розмиву берми в окремих створах складав $(15-20) \%$. Глибина воронки розмиву поблизу траверс досягала $(0,04-0,06)$ м або у натурі $(0,8-1,2)$ м. 


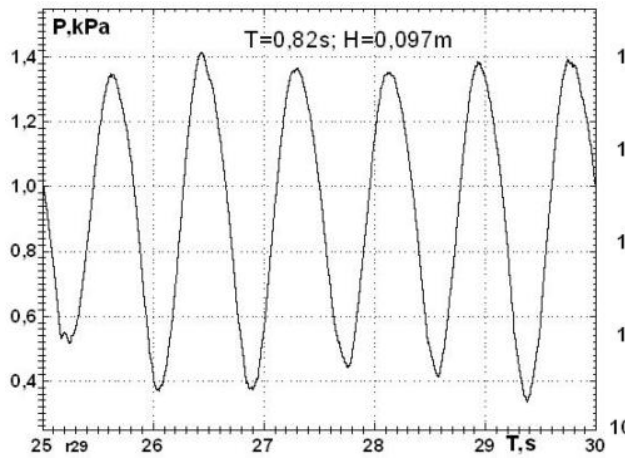

a)

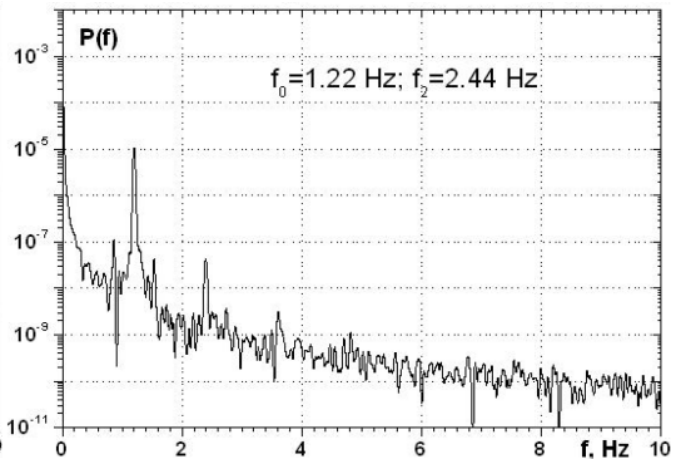

б)

Рис. 4 - Осцилограма хвильового руху (а) та спектральна густина потужності пульсацій хвильового тиску (б) на глибокій воді
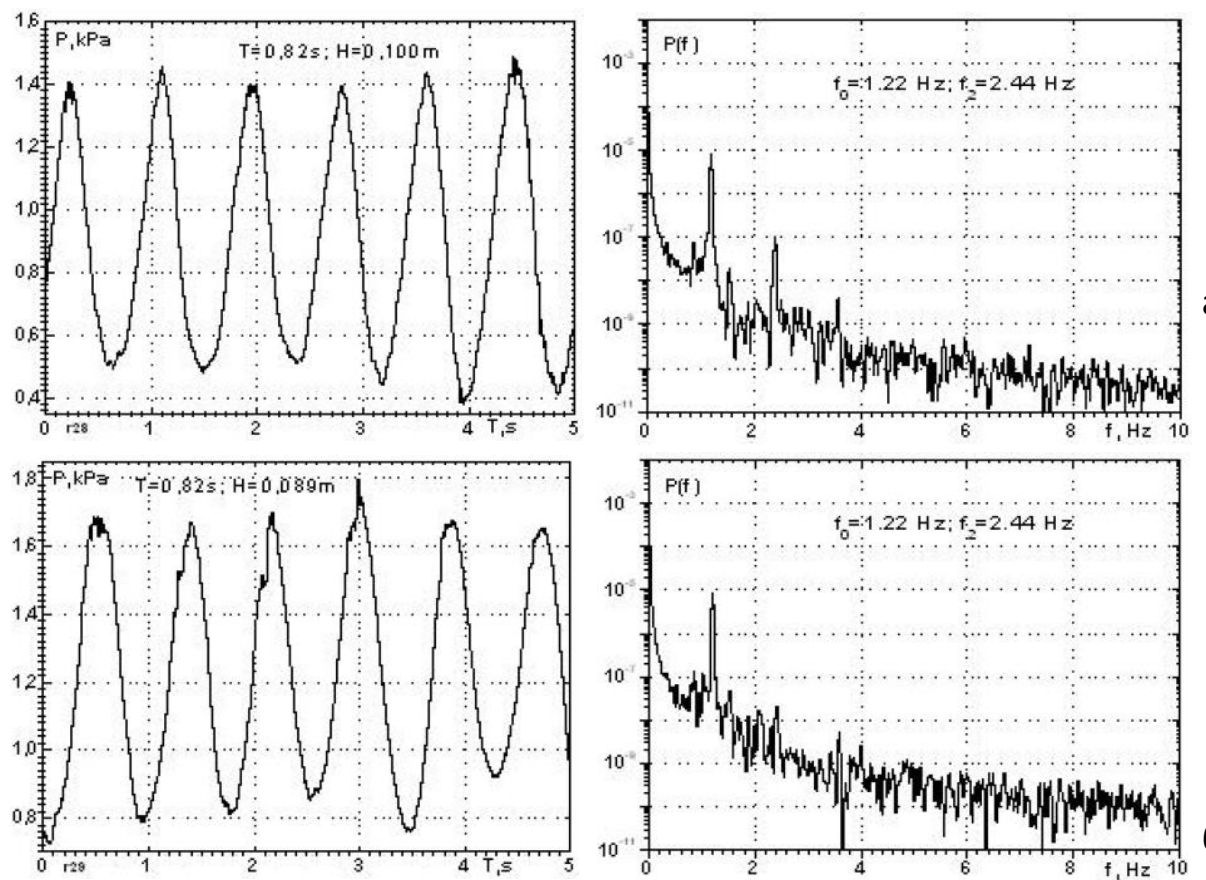

б)
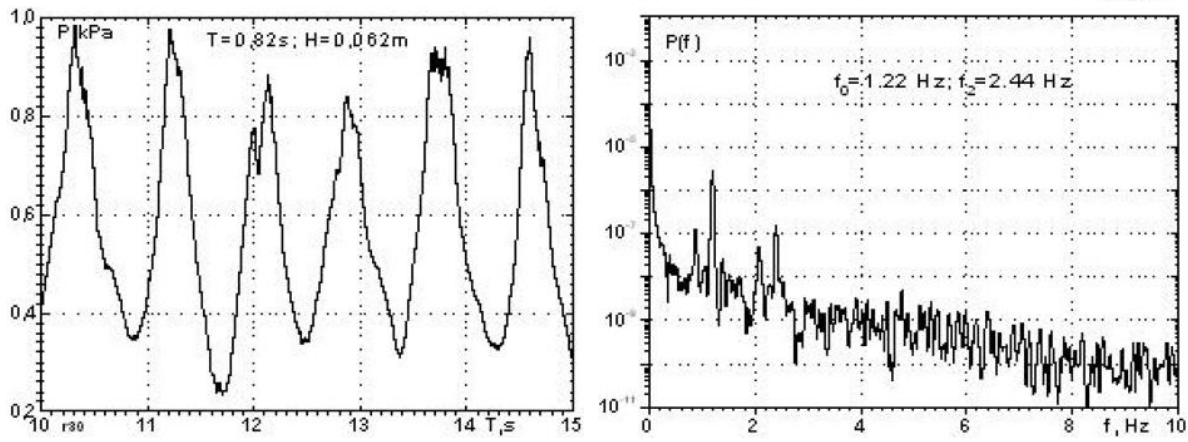

Рис. 5 - Параметри хвиль та хвильового тиску до руйнування хвиль (а), в області обвалення хвиль (б) та на рівні голів бун (в) 


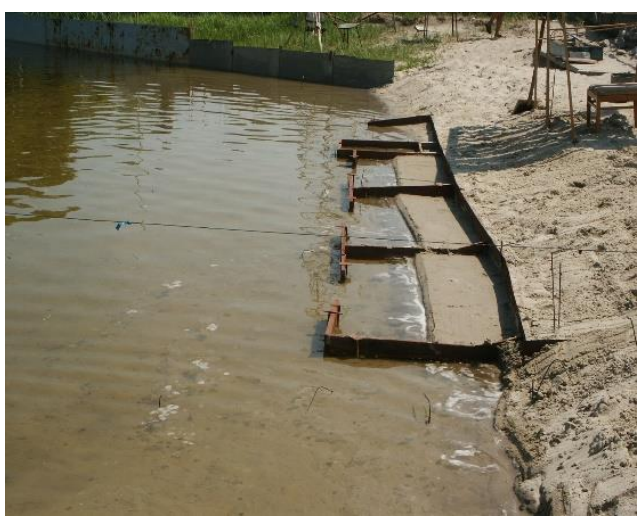

a)

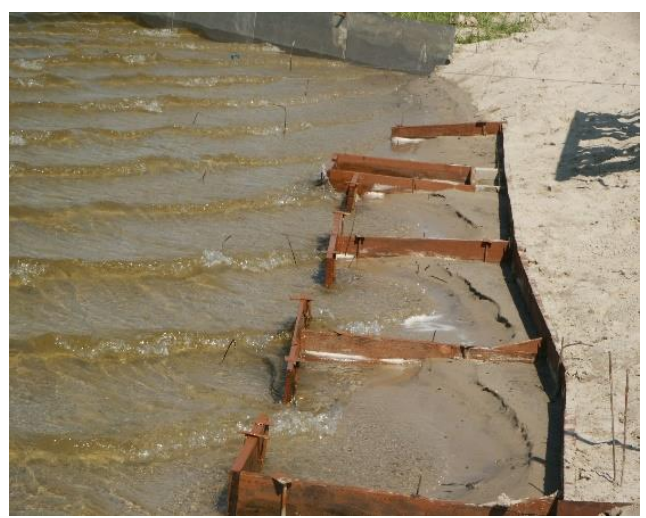

б)

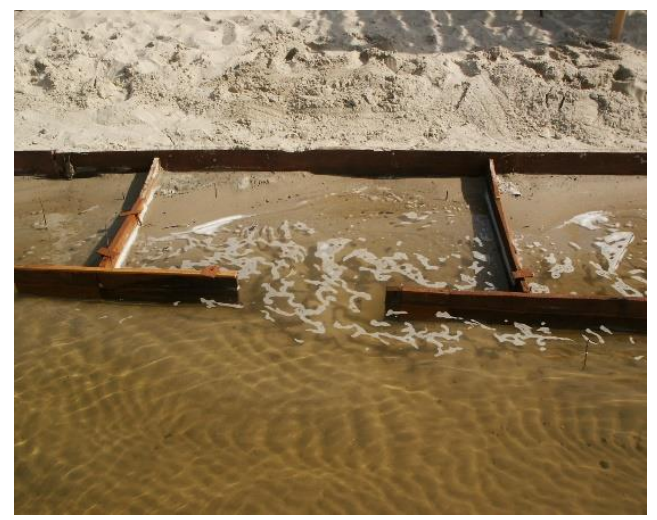

в)

Рис. 6 - Загальний вигляд моделі берега з Т-подібними хвилеломами до (а), під час (б) та після (в) проведення досліджень

У той же час техніко-економічні порівняння показують, що створення бухт за допомогою траверс призводить до збільшення фронту захисту в 1,3 раза (130\%). Крім того, відбивання хвиль від стінки траверса призводить до формування нерівномірного хвильового режиму в формі биття і неповної стоячої хвилі, що ускладнює вхід в ворота бухти плавзасобів.

Дослідження хвильового руху та спектральних складових пульсацій хвильового тиску показали, що суттєвих змін у характері поведінки хвильового руху не спостерігалося. На рівні критичних глибин порушувалася форма гребнів хвиль, а в області обвалення хвиль і поблизу відкосу модельного пляжу хвилі руйнувалися. Поблизу поверхонь хвилеломів спостерігалося значне руйнування та збільшення висоти хвиль, які були на (30-50)\% вищі, ніж посередині міжбунних акваторій на рівні площини хвилеломів.

Зміна конструкції хвилеломів у вигляді розтрубів (кут розкриття (120-130) градусів), які утворено двома відрізками (див., рис. 7), призвела до зміни хвильового руху у прибережній зоні та вплинула на поведінку рекреаційного пляжу. Застосування V-подібних хвилеломів 3 бунними траверсами привело до зменшення хвильового навантаження на модель піщаного пляжу, особливо в зонах, які прилягають до берегозахисних конструкцій. V-подібні хвилеломи суттєво захистили бухти від дії косого 
хвилевого руху. При цьому напрямок хвиль на вході у бухти став більше фронтальним, а висоти хвиль значно зменшилися та стали більше хаотичними. По суті справи кормові частини хвилеломів у вигляді розтрубів спрямували основний хвильовий потік назовні з бухти у відкрите море, руйнуючи хвилі. Взаємодія хвиль 3 конструкціями хвилеломів призвела до значних розмивів грунту поблизу хвилеломів і на вході до створених бухт, що показано на рис. 7в.

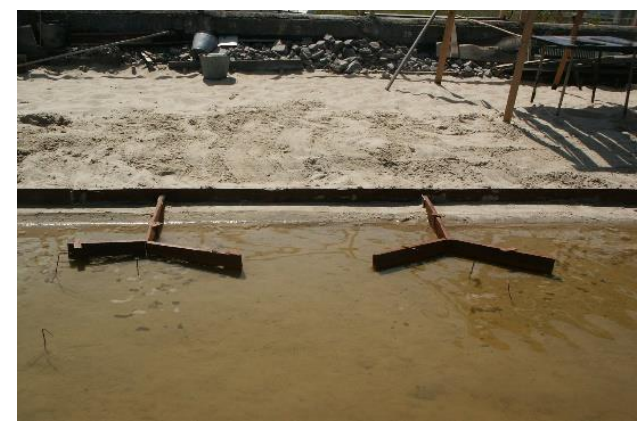

a)

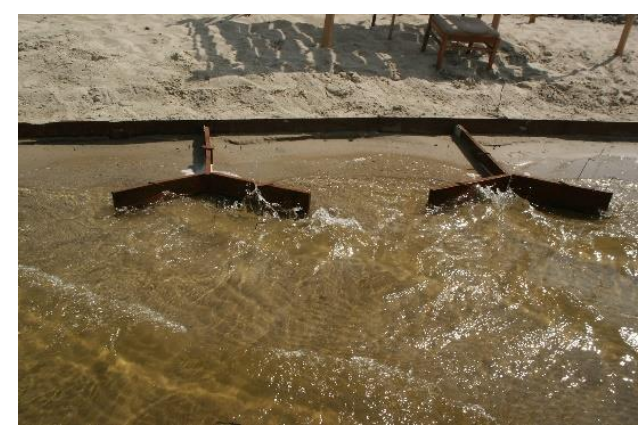

б)

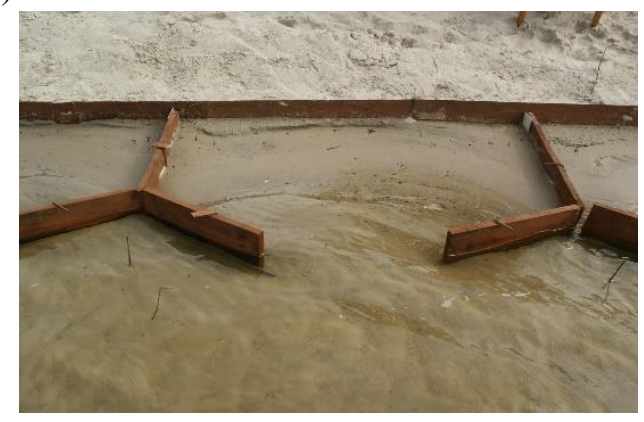

B)

Рис. 7 - Загальний вигляд моделі берега $3 \mathrm{~V}$-подібними хвилеломами 3 траверсами до (а), під час (б) та після (в) проведення досліджень

Спектральні складові хвильового тиску поблизу хвилеломів і вхідної частини бухт значно збільшилися в області високих частот і зменшилися в області низьких частот, особливо на основній частоті хвильового руху та на їі вищих гармоніках.

Трансформація хвиль і розподіл швидкостей вздовж берегової лінії 3 використанням досліджених моделей берегозахисних споруд наведені схематично на рис. 8. На цьому рисунку колами наведені місця заміру висот хвиль та їх значення, а трикутничками - місця заміру та значення швидкостей течії. У верхній частині рис. 8 стрілочкою показаний напрямок косого підходу хвильового руху в штормових умовах до берегозахисних споруд. Треба зазначити, що застосування бун, як берегозахисних споруд, викликає значне зменшення швидкості течії вздовж захищеного берега (див., рис. 8а) і висот хвиль як поблизу головних частин бун, так і на вхідних ділянках створених бухт. Хвилеломи з траверсами значно збільшують швидкість бічної течії мористіше від цих споруд та зменшують дію хвильового руху на захищені піщані пляжі. 


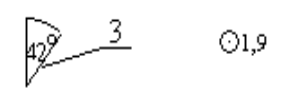

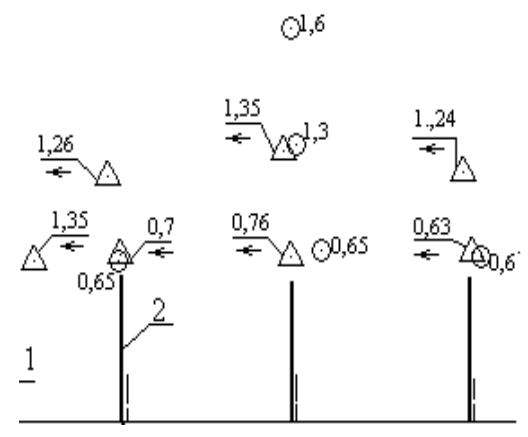

a)

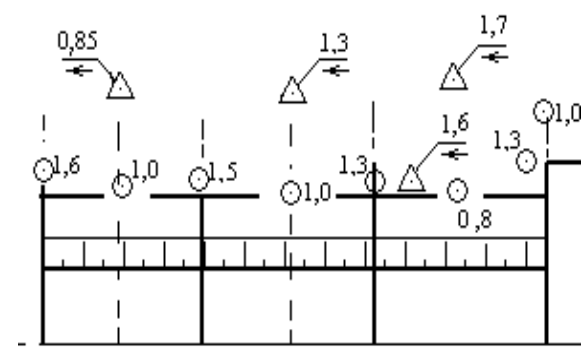

б)

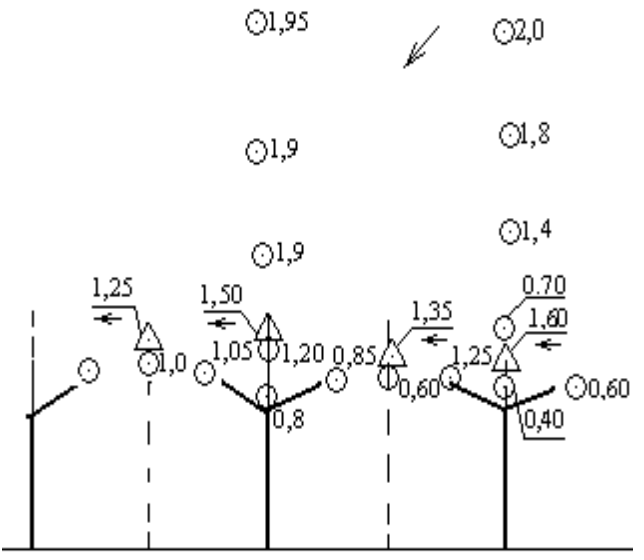

в)

Рис. 8 - Схема поля висот хвиль (м) і швидкостей течій (м/с) на моделях захисту пляжів бунами (a), T-подібними (б) та V-подібними (в) хвилеломами з траверсами під дією хвиль розрахункового шторму з косим підходом до берега

Враховуючи результати проведених досліджень і рекомендації, які надано проектувальникам i будівельникам берегозахисних споруд, поблизу оздоровчого комплексу “Урзуф” були зведені системи бун, які представлено на рис. 9. Ці споруди було використано на практиці в першу чергу через те, що буни, з точки зору економічної доцільності та тривалості будівництва, були найбільш ефективні. Хвилеломи, маючи відповідні переваги 3 точки зору гідродинаміки, не знайшли застосування в цьому проекті.

\section{Висновки}

1. Установлено, що ефективними берегозахисними спорудами активного способу захисту, які можуть бути використані в умовах дефіциту наносів хвильового поля в області Азовського моря, є буни, хвилеломи та хвилеломи 3 траверсами. Застосування переривчастих хвилеломів чи створення бухтового 


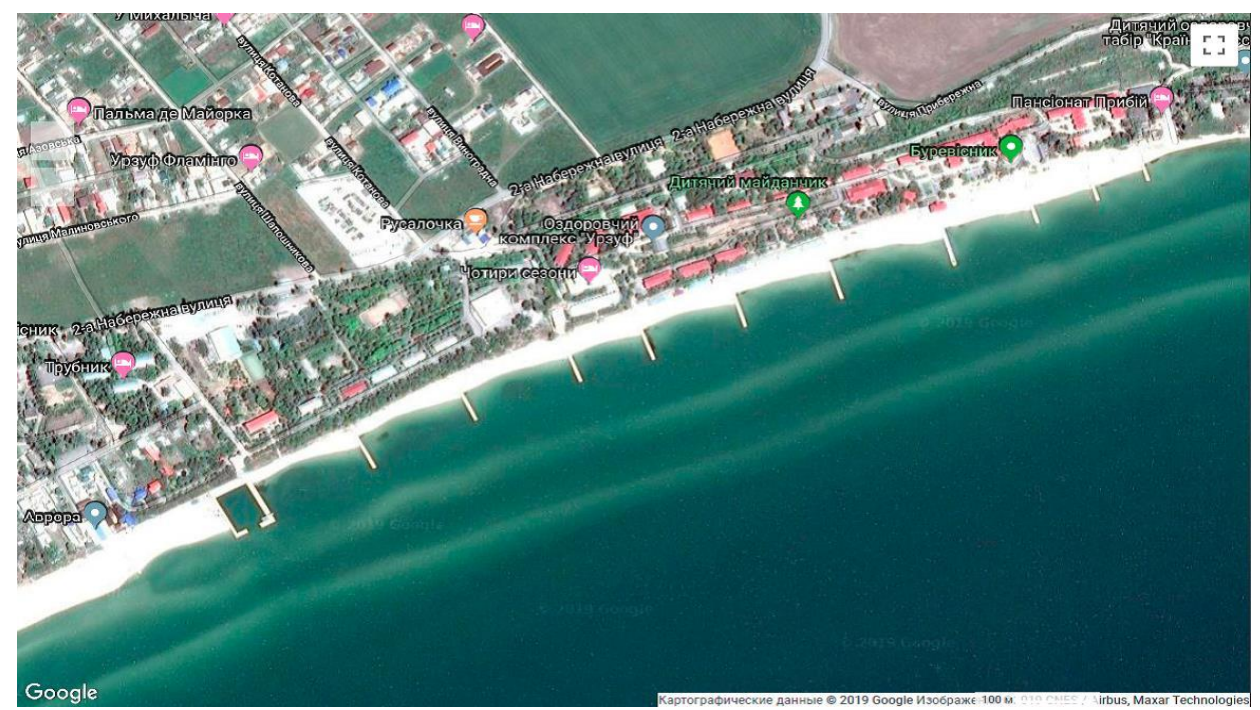

Рис. 9 - Розташування системи бун з захисту рекреаційного пляжу оздоровчого комплексу “Урзуф” на березі Азовського моря

берега 3 використанням бун 3 траверсами чи бун з V-подібними раструбами призводить до консервації природнього та штучного пляжів з утворенням стійкої берегової лінії. Але застосування хвилеломів 3 траверсами потребує великих одноразових грошових вкладень і значних будівельних зусиль. Тому ефективними берегозахисними спорудами активного способу дії поблизу оздоровчого комплексу "Урзуф" запропоновано та створено систему бун в комбінації з штучною пляжною відсипкою.

2. Рекомендовано розташовувати голови бун приблизно на глибині 1,5 м нижче відмітки середньобагаторічного рівня моря, але не мористіше підводного вала. На перехідних ділянках берегозахисту використовувати укорочені буни. Починаючи 3 другої буни, зробити горизонтальну піщану берму на відмітці $+1,5$ (шириною 20 м) до восьмої буни. 3 восьмої по дев'яту буну ширина берми 15 м та до кінця ділянки ширина берми 25 м. Напірний відкіс берми сполучити з існуючим пляжем ухилом 0,2.

3. Під час експлуатації даної системи бун: а) наявність берми рекомендованої ширини забезпечить нормальну експлуатацію споруд та збереження надводної частини пляжу при дії розрахункових штормів від можливих хвиленебезпечних напрямків; б) для випадку ймовірного накладення дії розрахункових штормів від різних напрямків для стійкості підводної частини пляжу треба зробити додаткову відсипку берми шириною 35 м. Якщо організація такого об'єму відсипки недоцільна з економічних міркувань, тоді потрібно робити ремонтні досипки. Об'єм та періодичність досипок визначати природними умовами та контролем за переміщенням лінії урізу води.

4. Визначено, що обрані методи берегозахисних споруд забезпечують захист берегів від руйнування 3 одночасним відновленням (утворенням) пляжів, які активно можуть бути використані в рекреаційних цілях у національних природних парках і санаторно-курортних зонах прибережної полоси Азовського і Чорного морів. 


\section{СПИСОК ЛІТЕРАТУРИ}

1. Хомицкий В.В. Природо-охранные аспекты береговой гидротехники / В.В. Хомицкий. - К.: Наукова думка, 1983. - 276 с.

2. Рекомендации по проектированию берегоукрепительных сооружений на водохранилищах. - К.: Минводхоз УССР, 1987. - 83 с.

3. ДБН В.1.1-25:2009 Захист від небезпечних геологічних процесів. Основні положення проектування. - К.: Міністерство 3 питань житлово-комунального господарства України, 2008. - 91 с.

4. Шуйский Ю.Д. Особенности природных комплексов в береговой зоне морей / Ю.Д. Шуйский // Вісник Одеського національного університету. Географічні та геологічні науки. - 2015. - Том 20. - Вип. 1 (24). - С. 97-113.

5. Михайличенко С.Ю. Трансформация поверхностных гравитационных волн при взаимодействии с берегозащитными сооружениями в прибрежной зоне с реальным рельефом дна / С.Ю. Михайличенко, Д.Ю. Куранов // Экология. Экономика. Информатика. - 2018. - Т.1, №3. - С. 65-70.

6. Гайворонская И.В. Пляжная зона как объект интегрированного рекреационного использования / И.В. Гайворонская // Механізм регулювання економіки. - 2010. - Т.2, №3. - C. 209-215.

7. Макаров К.Н. Современные методы повышения устойчивости рекреационных пляжей / К.Н. Макаров, В.А. Приходько, Е.В. Радченко // Курортно-рекреационный комплекс в системе регионального развития: Инновационные подходы. - 2016. - №1. C. 255-258.

8. Anton I.-A. Wave simulation with different type of coast protection structure A comparative approach / I.-A. Anton, D. Dinu // International Journal of Environmental Science. - 2017. - Vol. 2. - P. 171-176.

9. Леонтьев И.О. Изменения контура берега, вызванные поперечным сооружением в береговой зоне моря / И.О. Леонтьев // Геоморфология. - 2018. - №3. - С. 32-39.

10. Dutta D. Performances of straight head and T-head groynes as river training structures / D. Dutta, H. M. Kalita // IOP Conf. Ser.: Mater. Sci. Eng. - 2019. - Vol. 491. - P. 012013$1-5$.

11. Choufu L. Investigation of flow, erosion, and sedimentation pattern around varied groynes under different hydraulic and geometric conditions: A numerical study / L. Choufu, S. Abbasi, H. Pourshahbaz, P. Taghvaei [et al.] // Water. - 2019. - №11. - P. 235-1-18.

12. Martinelli L. Experimental investigation on non-breaking wave forces and overtopping at the recurved parapets of vertical breakwaters / L. Martinelli, P. Ruol, M. Volpato, C. Favaretto [et al.] // Coastal engineering. - 2018. - Vol. 141. - P. 52-67.

13. Тучковенко Ю.С. Моделирование трансформации ветровых волн в прибрежной зоне моря при различных вариантах реконструкции волнолома / Ю.С. Тучковенко, О.И. Сахненко // Український гідрометеорологічний ж. - 2017. - №2. - С. 175-185.

14. Khomicky V. Physical and mathematical modeling of permeable breakwaters / V. Khomicky, L. Tereshchenko, L. Abramova, I. Tereshchenko [et al.] // In: Hu Z., Petoukhov S., Dychka I., He M. (eds) Advances in Computer Science for Engineering and Education. ICCSEEA 2018. Advances in Intelligent Systems and Computing, vol 754. Springer, Cham. - 2019. - P. 3-12.

15. Di Lauro E. Stability analysis of a non-conventional breakwater for wave energy conversion / E. Di Lauro, J.L. Lara, M. Maza, I.J. Losada [et al.] // Coastal engineering. 2019. - Vol. 145. - P. 36-52.

16. Лаппо Д.Д. Условия автомодельности в исследованиях волнового движения жидкости / Д.Д. Лаппо, А.М. Жуковец, С.С. Мищенко // Изв. ВИНИТИ им. Веденеева. - 1979. - T. 132. - C. 59-65.

17. Voskoboinick V. Study of near wall coherent flow structures on dimpled surfaces using unsteady pressure measurements / V. Voskoboinick, N. Kornev, J. Turnow // Flow Turbulence Combust. - 2013. - Vol. 90, №4. - P. 709-722. 
18. Voskoboinick V.A. Pressure fluctuations on the scour surface before prismatic pier / V.A. Voskoboinick, A.V. Voskoboinick, O.O. Areshkovych, O.A. Voskoboinyk // Proc. $8^{\text {th }}$ International Conference on Scour and Erosion (ICSE 2016) 12-15 September 2016. Oxford, UK, 2016. - P. 905-910.

19. Бендат Дж. Измерение и анализ случайных процессов : Пер. с англ. / Дж. Бендат, А. Пирсол. - М. : Мир, 1974. - 464 с.

20. Tereshchenko L. Statistical analysis of jet flow noise across bileaflet heart valve / L. Tereshchenko, V. Voskoboinick, I. Kudybin, A. Voskoboinick [et al.] // Abstract AMMODIT-2019. - Kyiv, Ukraine, 2019. - P. 52-53.

21. Vinogradnyi G.P. Spectral and correlation characteristics of the turbulent boundary layer on an extended flexible cylinder / G.P. Vinogradnyi, V.A. Voskoboinick, V.T. Grinchenko, A.P. Makarenkov // J. Fluid Dyn. - 1989. - Vol. 24, № 5. - P. 695-700.

Стаття надійшла до редакиії 05.11.2019 і прийнята до друку після рецензування 27.11.2019

\section{REFERENCES (TRANSLATED AND TRANSLITERATED)}

1. Khomicky, V. V. (1983). Pryrodo-okhrannye aspekty beregovoy gidrotekhniki. Kyiv: Naukova dumka. (in Russian).

2. Minvodkhoz USSR. Rekomendacii po proektirovaniyu beregoukrepitel'nykh sooruzheniy na vodokhranilischakh. (1987). Kyiv. (in Russian).

3. DBN B.1.1-25:2009. (2008). Zakhyst vid nebezpechnykh geologichnykh processiv. Osnovni polozhennya proektuvannya. Kyiv: Ministerstvo z pytan' zhytlovo-komunal'nogo gospodarstva Ukraine. (in Ukrainian).

4. Schuisky, Yu. D. (2015). Osobennosti prirodnykh kompleksov v beregovoi zone morey. Visnyk Odes'kogo nacional'nogo universytetu. Geografichni ta geologichni nauky, 20(24), 97-113. (in Russian).

5. Mykhailichenko, S. Yu. (2018). Transformaciya poverkhnostnykh gravitacionnykh voln pri vzaimodeystvii s beregozashchitnymi sooruzeniyami v pribreznoy zone s real'nym rel'efom dna. Ekology. Ekonomics. Informations, 1(3), 65-70. (in Russian).

6. Gaivoronskaya, I. V. (2010). Plyaznaya zona kak ob'ekt integrirovannogo rekreacionnogo ispol'zovaniya. Mekhanizm regulyuvannya ekonomiky, 2(3), 209-215. (in Russian).

7. Makarov, K. N., Prikhod'ko, V. A., \& Radchenko, E. V. (2016). Sovremennye metody povysheniya ustoichivosti rekreacionnykh plyazhey. Kurortno-rekreacionnyi komplex $v$ sisteme regional 'nogo razvitiya: Innovacionnye podkhody, 1, 255-258. (in Russian).

8. Anton, I.-A. (2017). Wave simulation with different type of coast protection structure A comparative approach. International Journal of Environmental Science, 2, 171-176.

9. Leont'ev, I. O. (2018). Izmeneniya kontyra berega, vyzvannye poperechnym sooruzheniem v beregovoi zone morya. Geomorfologiya, (3), 32-39. (in Russian).

10. Dutta, D., \& Kalita, H. M. (2019). Performances of straight head and T-head groynes as river training structures. IOP Conf. Ser.: Mater. Sci. Eng., 491, 012013-1-5.

11. Choufu, L., Abbasi, S., Pourshahbaz, H., Taghvaei, P. [et al.]. (2019). Investigation of flow, erosion, and sedimentation pattern around varied groynes under different hydraulic and geometric conditions: A numerical study. Water, (11), 235-1-18.

12. Martinelli, L., Ruol, P., Volpato, M., Favaretto, C. [et al.]. (2018). Experimental investigation on non-breaking wave forces and overtopping at the recurved parapets of vertical breakwaters. Coastal engineering, 141, 52-67.

13. Tuchkovenko, Yu. S., \& Sakhnenko, O. I. (2017). Modelirovanie transformacii vetrovykh voln $\mathrm{v}$ pribrezhnoi zone morya pri razlichnykh variantakh rekonstrukcii volnoloma. Ukrainskii gidrometereologichesrii j., (2), 175-185. (in Russian). 
14. Khomicky, V., Tereshchenko, L., Abramova, L., Tereshchenko, I., [et al.]. (2019). Physical and mathematical modeling of permeable breakwaters. In: Hu Z., Petoukhov S., Dychka I., He M. (eds) Advances in Computer Science for Engineering and Education. ICCSEEA 2018. Advances in Intelligent Systems and Computing, 754, 3-12.

15. Di Lauro, E., Lara, J. L., Maza, M., Losada, I. J. [et al.]. (2019). Stability analysis of a non-conventional breakwater for wave energy conversion. Coastal engineering, 145, 36-52. 16. Lappo, D. D., Zhukovec, A. M., Mishchenko, S. S. (1979). Usloviya avtomodel'nosti v issledovaniyakh volnovogo dvizheniya zhidkosti. Izv. VINITI im. Vedeneeva, 132, 59-65. (in Russian).

17. Voskoboinick, V., Kornev, N., Turnow, J. (2013). Study of near wall coherent flow structures on dimpled surfaces using unsteady pressure measurements. Flow Turbulence Combust, 90(4), 709-722.

18. Voskoboinick, V. A., Voskoboinick, A. V., Areshkovych, O. O., \& Voskoboinyk, O. A. (2016). Pressure fluctuations on the scour surface before prismatic pier. In Proc. 8th International Conference on Scour and Erosion (ICSE 2016) 12-15 September 2016 (pp. 905-910). Oxford.

19. Bendat, J., \& Pirsol, A. (1974). Izmerenie I analiz sluchainykh processov. Moscow: Mir. (in Russian).

20. Tereshchenko, L., Voskoboinick, V., Kudybin, I., \& Voskoboinick, A. (2019). Statistical analysis of jet flow noise across bileaflet heart valve. In Abstract AMMODIT-2019 (pp. 52-53). Kyiv, Ukraine.

21. Vinogradnyi, G. P., Voskoboinick, V. A., Grinchenko, V. T., \& Makarenkov, A. P. (1989). Spectral and correlation characteristics of the turbulent boundary layer on an extended flexible cylinder. J. Fluid Dyn., 24(5), 695-700.

The article was received 05.11.2019 and was accepted after revision 27.11.2019

\section{Хомицький Віталій Володимирович}

кандидат технічних наук, старший науковий співробітник, провідний науковий співробітник відділу Прикладної гідродинаміки Інституту гідромеханіки НАН України

Адреса робоча: 03057, Україна, Київ, вул. Марії Капніст, 8/4

ORCID ID: 0000-0003-0910-2233 e-mail: homicky@ukr.net

\section{Воскобійник Володимир Анатолійович}

доктор технічних наук, старший науковий співробітник, провідний науковий співробітник відділу Гідробіоніки та керування примежовим шаром Інституту гідромеханіки НАН України

Адреса робоча: 03057, Україна, Київ, вул. Марії Капніст, 8/4

ORCID ID: 0000-0003-2161-6923 e-mail: vlad.vsk@gmail.com

\section{Харченко Анатолій Григорович}

головний інженер-електрик відділу Прикладної гідродинаміки Інституту гідромеханіки НАН України

Адреса робоча: 03057, Україна, Київ, вул. Марії Капніст, 8/4

ORCID ID: 0000-0002-5832-7714 e-mail: kharchenko62@gmail.com

\section{Воскобойник Олександр Анатолійович}

кандидат технічних наук, старший науковий співробітник відділу Технічної гідромеханіки Інституту гідромеханіки НАН України

Адреса робоча: 03057, Україна, Київ, вул. Марії Капніст, 8/4

ORCID ID: 0000-0001-8114-4433 e-mail: alexandr.vsk@gmail.com 


\section{Терещенко Лідія Миколаївна}

кандидат технічних наук, старший науковий співробітник, старший науковий співробітник відділу Прикладної гідродинаміки Інституту гідромеханіки НАН України

Адреса робоча: 03057, Україна, Київ, вул. Марії Капніст, 8/4

ORCID ID: 0000-0001-6068-7092 e-mail: litere70@gmail.com

\section{Воскобійник Андрій Володимирович}

кандидат технічних наук, старший науковий співробітник, старший науковий співробітник відділу Гідробіоніки та керування примежовим шаром Інституту гідромеханіки НАН України

Адреса робоча: 03057, Україна, Київ, вул. Марії Капніст, 8/4

ORCID ID: 0000-0001-8045-8625 e-mail: andrew.vsk@gmail.com

\section{Нікітін Іван Анатолійович}

провідний інженер відділу Прикладної гідродинаміки Інституту гідромеханіки НАН України

Адреса робоча: 03057, Україна, Київ, вул. Марії Капніст, 8/4

ORCID ID: 0000-0001-5906-2538 e-mail: nia37@ukr.net 